\title{
WORK ENGAGEMENT: ORGANIZATIONAL CULTURE POINT OF VIEW
}

\author{
Elena Rodionova ${ }^{1}$, \& Vladislav Dominiak ${ }^{2}$ \\ ${ }^{1}$ Department of psychology, St. Petersburg State University (Russia) \\ ${ }^{2}$ Graduate School of Management, St. Petersburg State University (Russia)
}

\begin{abstract}
Introduction. Currently, the problem of employee work engagement is one of the most urgent in the field of employee management. A high degree of work engagement of employees directly affects the efficiency of organizations and labor productivity. The study attempted to consider the value determinants of work engagement of employees, such as the value correspondence of employees and organizations, aspiration index (internal, external). We assumed that the level and indicators of work engagement (vigor, dedication, absorption) are directly related to the index of the realization of employee's value expectations in the organization and their internal aspiration index.

Employees with a high level of engagement have a positive impact on the quality of their organization's products (Schaufeli, Salanova, 2011). The results of our study allow us contribute to understanding the value aspects of employees work engagement, creating and supporting the «We-concept» of organizations to increase their effectiveness.

Method. Research sample consist the employees of three various organizations and their direct heads. 90 people, 57 women and 73 men aged from 20 up to 60 years participated in the study. The following techniques were used: "Utrecht work engagement scale" (UWES) (Schaufeli, Bakker, 2003), "Organizational Culture Assessment Instrument" (OCAI) by K. Cameron and R. Quinn, "Aspiration index" (Desi, Ryan, 2017) или (Kasser, Ryan, 1996). The data was processed by descriptive statistics, correlation and multiple regression analysis.

The result of the work is to assess the contribution of the evaluations ratio of preferred and present organizational culture and aspiration index to the work engagement.
\end{abstract}

Keywords: Work engagement, value expectations, aspiration index, organizational culture.

\section{Introduction}

The problem of employee's work engagement has become increasingly interested for heads of organizations and business owners. Leaders try to measure and manage the quantitative and qualitative characteristics of engagement. A HR.com study report on the status of work engagement in 2019 indicates that more than $90 \%$ of respondents link work engagement and performance, customer service and productivity (The State of Employee Engagement in 2019). This, first of all, indicates the popularity of work engagement concept. At the same time, there are many evidences of relationship between work engagement and performance. For example, the same study showed that "highly engaged organizations are more than twice as likely to report being top financial performers in their industries" (ibid., p. 5). Another example is a study of Czech workers in assisting professions, in which it was found that only work engagement is related to performance, but not job satisfaction. "Engaged people perform better than their less engaged peers" (Kasparkova et al., 2018, p. 53). A lot of research shows the relationship between the desired results of a company and its employee engagement, for example, high-quality customer service, retaining talented people, team performance, labor productivity, unit productivity, and even financial indicators at the enterprise level (e.g. Motyka, 2018; Wake, Green, 2019; Munish, Agarwal, 2017, etc.).

In this regard, the question arises of determining the factors of employee engagement. In our work, we suggested that the employees work engagement is significantly affected by the value correspondence of employees and organizations, expressed in the ratio of preferred and real organizational culture. By organizational culture we understand a three-level dynamic system of interaction between the organization and employees (values - attitudes - behavior, action), which 
(interaction system) is expressed in a certain style, organization philosophy, business processes, features of external adaptation and internal integration and ensures the effectiveness of the organization (Rodionova, 2010).

\section{Methods}

Objective: to explore the relationship between organizational culture assessments and employee's work engagement.

Object of study. Research sample consist the employees of three various organizations and their direct heads. 90 people, 57 women and 73 men aged from 20 up to 60 years participated in the study. The study took place in St. Petersburg.

The following techniques were used: "Utrecht work engagement scale" (UWES) (Schaufeli, Bakker, 2003), "Organizational Culture Assessment Instrument" (OCAI) by K. Cameron and R. Quinn, "Aspiration index" (Desi, Ryan, 2017) или (Kasser, Ryan, 1996). The data was processed by descriptive statistics, correlation and multiple regression analysis.

\section{Results}

During the analysis of data obtained during the study, we identified three groups according to the level of work engagement:

Low level of engagement (7.5\% of employees);

Average level of engagement ( $85 \%$ of employees);

High level of involvement ( $7.5 \%$ of employees).

For employees with a low level of engagement, the minimization of additional efforts in relation to the company is characteristic. They cope with the tasks at an acceptable level, but, as a rule, they are limited by what is regulated by their position, rarely do something beyond the time limit. Often, low levels of engagement are employees recently working in the company, being in training or in the adaptation process.

Employees with an average level of engagement are characterized by the fact that they are not only motivated to work beyond the prescribed position, but also transmit their interest in developing the organization to other employees. These are, as a rule, employees with extensive experience in this organization.

A high level of engagement characterizes the participation of employees not only in the working life of the organization, but also in activities related to the organization and the team outside working hours. They are not only deeply involved themselves, but also influence colleagues, transmitting to them their attitude to work and organization.

Based on the results obtained, a general organizational profile of the present and preferred organizational culture for the sample was constructed (Figure 1).

Figure 1. Comparison of real and preferred profiles of organizational culture for the sample.

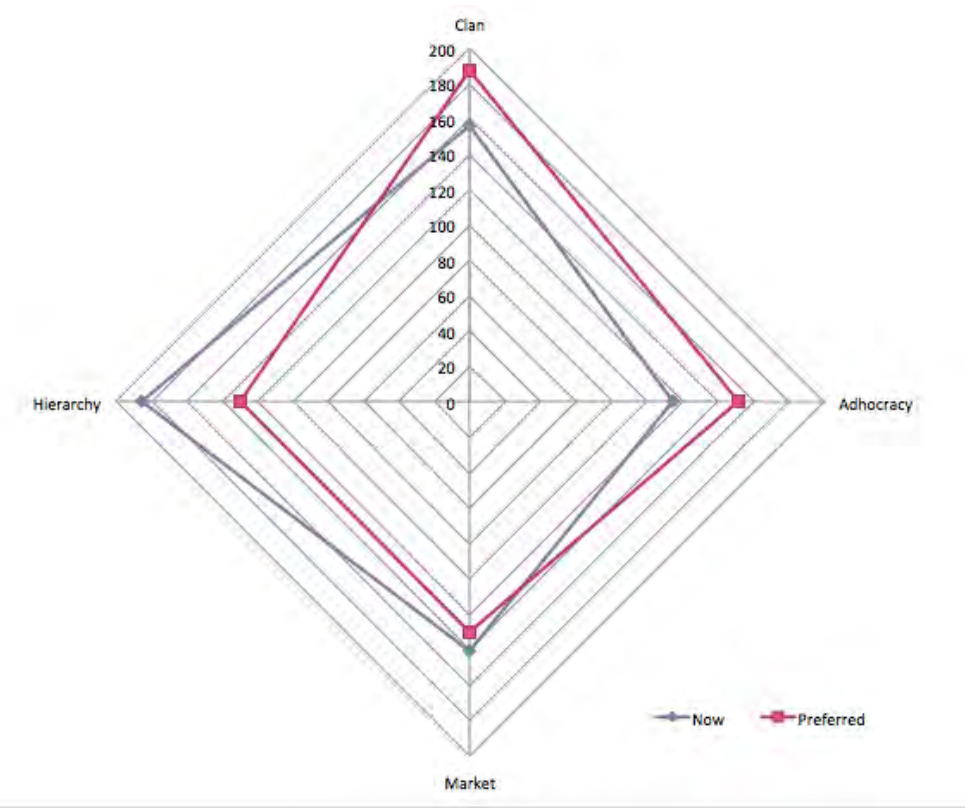


Analyzing the resulting profile, we can conclude that at present, according to employees, the company is dominated by a hierarchical type of culture. The company is committed to formal rules and official policies. The concern of the organization is to ensure the stability of indicators and the long-term employment of employees.

To a lesser extent, but nevertheless, at a significant level, employees note the "clannishness" inherent in organizational culture. This can be explained by the specifics of building a work process: as a rule, several employees are allocated to work on a project, depending on the project, the composition of the working group may change. This contributes to the development of relations between employees, increasing cohesion, complicity, individuality and a sense of organization as "we", a friendly atmosphere is formed, often many employees have common interests. The head of the project team - team lead is perceived as a mentor with great experience and knowledge, and not as an administrator with administrative powers. Statistically significant differences were obtained between estimates of the real and preferred types of culture, in particular, for hierarchical, adhocratic, and clan cultures. That is, employees are focused on greater independence, freedom in tactical decisions, delegation of authority and building partnerships.

For a more informative presentation of the real desired organizational culture, profiles of its six separate attributes were constructed, which were distinguished by K. Kameron and R. Quinn:

- the most important characteristics of the organization;

- general leadership style;

- management of employees in the company;

- the connecting essence of the organization;

- strategic goals;

- key success criteria.

The largest discrepancies (statistically significant) are observed in the sphere of managing hired workers (I want more independence and less formalization of the process and results) and the "connecting essence of the organization". According to the opinion of employees, the essence of the company should be the balance of attributes of a clan and adhocratic culture. This implies a combination of the attitude towards the employee as the company's capital (emphasis on the long-term benefits of personal development, a high degree of team cohesion and a favorable moral climate), as well as a dedication to experimentation and innovation. In the context of the innovative company, we are talking about attracting new, sometimes risky projects, development of innovations, and the use of non-standard solutions.

We got mixed results of relationships of work engagement indicators with implementation index of employee's value expectations in the organization. We received the contribution of the implementation index of employee's value expectations, committed to certain types of organizational culture, with the indicator of work engagement in general ( $\mathrm{R}$-square $=0,25)$. In addition, work engagement relationship with the internal aspiration index was obtained $(\mathrm{R}$-square $=0,53)$. This allowed us to build a value space model of the organization, which contributes to an increase in the level of employee engagement.

\section{Conclusions}

In both science and business, work engagement has been and continues to be seen as a favorable factor for the development and success of an organization. Organizational factors such as relate to the formation of engagement include: attitude to the organization's leadership and immediate supervisor; the opportunity to participate in management, influence decision-making, as well as awareness of events and plans; confidence that employees are important to the organization adoption by employees of organizational goals and values; satisfaction with work organization and work. In this case, we are talking about the role of organizational culture as a factor in shaping employee engagement. The correspondence of employees value and values of organization can, at least by a quarter, contribute to the formation of a high level of employee engagement. In addition, a study of the relationship between employee engagement and organizational culture indicators can allow company leaders and HR professionals to maintain a stable competitive advantage for the organization in the market by optimizing the characteristics of the organizational culture of the company and hiring employees that match the organization's value characteristics.

At the same time, we understand that not only organizational, but also personal and social factors (for example, age, length of service, relationships in a team, etc.) influence the work engagement. Employee engagement cannot exist on its own, out of touch with the internal environment of the company or in isolation from key business processes. 
The data obtained by us can be demanded when working with the personnel of the company under study to create an environment conducive to increasing employee work engagement, as well as developing a system of employee motivation in order to increase the effectiveness of the organization and create a positive image of the employer among the staff.

\section{References}

Kameron K., Quinn, R. (2001) Diagnosing and Changing Organizational Culture. СПб: Питер. - 320 c. Kašpárková, L., Vaculík, M., Procházka, J., Schaufeli, W.B. (2108). Why resilient workers perform better: The roles of job satisfaction and work engagement // Journal of Workplace Behavioral Health, 33 (1), 43-62. https://doi.org/10.1080/15555240.2018.1441719

Munish, Agarwal, R. (2017). Employee Engagement and Retention: a Review of Literature // International Journal of BRIC Business Research (IJBBR), 6 (1), 1-19.

Rodionova E. A. (2010). Kontseptsiya organizatsionnoy kul'tury v professional'noy deyatel'nosti // Psikhologicheskoye obespecheniye professional'noy deyatel'nosti: teoriya i praktika / pod red. G.S. Nikiforova. - SPb., Rech', 342-385.

Ryan, R. M., Deci, E. L. (2017). Self-determination theory: basic psychological needs in motivation, development, and wellness. - The Guilford Press.

Schaufeli, W., Bakker A. (2003). Utrecht Work Engagement Scale // Occupational Health Psychology Unit Utrecht Version 1, November 2003. - 58 p.

The State of Employee Engagement in 2019. (2019). www.hr.com | 877-472-6648, Retrieved December 8, 2019, from: https://cdn2.hubspot.net/hubfs/1973303/Content\%20Assets/HR.com\%20State\% 20of\%20Employee\%20Engagement\%202019\%20Report.pdf

Wake, M., Green, W. (2019). Relationship between employee engagement scores and service quality ratings: analysis of the National Health Service staff survey across 97 acute NHS Trusts in England and concurrent Care Quality Commission outcomes (2012-2016) // BMJ Open 2019. doi:10.1136/bmjopen-2018-026472. 